\title{
Biochemical Studies in Buffaloes Treated with Various NSAIDS Protocols Affected with Diaphragmatic Hernia
}

\author{
Lokesh $^{1}$, Praveen Kumar ${ }^{2 *}$, Anup Yadav ${ }^{3}$, Umed Singh Mehra $^{3}$, Rishi Tayal ${ }^{1}$, \\ Rajendra Yadav ${ }^{4}$ and Pankaj Kumar ${ }^{5}$ \\ ${ }^{1}$ Department of Veterinary Surgery, ${ }^{2}$ Department of Veterinary Medicine, ${ }^{3}$ Department of \\ Veterinary Gynaecology and Obstetrics (LUVAS, Hisar), Haryana, India \\ ${ }^{4}$ RVDEC, Mahendergarh (LUVAS, Hisar), Haryana, India \\ ${ }^{5}$ Disease Investigation Laboratory, Rohtak (LUVAS, Hisar), Haryana, India
}

*Corresponding author

\section{A B S T R A C T}

\begin{tabular}{|c|c|}
\hline & avity through \\
\hline Keywords & herniates into the thorax, however, the omasum, abomasum, loop of intestine, spleen or \\
\hline $\begin{array}{l}\text { Diaphragmatic } \\
\text { hernia, Biochemical } \\
\text { parameters, } \\
\text { Rumenotomy }\end{array}$ & $\begin{array}{l}\text { liver may also get involved without exhibiting additional specific clinical signs. The } \\
\text { disease is generally associated with the presence of foreign bodies in the reticulum. The } \\
\text { present investigation was conducted on eighteen clinical cases of buffaloes suffering from } \\
\text { diaphramatic hernia presented to the Teaching Veterinary Clinical Complex, LUVAS, }\end{array}$ \\
\hline Article Info & $\begin{array}{l}\text { Hisar from August } 2013 \text { to May } 2014 \text { and these were divided into three groups of six } \\
\text { animals each. Various biochemical parameters were observed/recorded before the animals }\end{array}$ \\
\hline $\begin{array}{l}\text { Accepted: } \\
22 \text { October } 2018 \\
\text { Available Online: } \\
10 \text { November } 2018\end{array}$ & $\begin{array}{l}\text { were operated for rumenotomy and were taken as base values. The present study concludes } \\
\text { that amid of plasma glucose levels rest of the biochemical parameters does not vary } \\
\text { significantly. Only in group } 2 \text { plasma albumin and total protein values show non- } \\
\text { significant progressive decrease in their respective base values at different time intervals of } \\
\text { treatment regime. A non-significant decrease was observed in plasma glucose levels in } \\
\text { group } 1 \text { and } 2 \text { while in group } 3 \text { it showed non-significant increase. }\end{array}$ \\
\hline
\end{tabular}

\section{Introduction}

Diaphragmatic hernia is defined as the passage of abdominal viscera into the thoracic cavity through a congenital or acquired opening in the diaphragm at the musculotendinous junction. It is a chronic wasting and inflammatory thoracoabdominal disorder in adult milk buffaloes (Sahu et al., 2003) and has also been reported in cows (Saini et al., 2007) and buffalo bulls (Sobti et al., 1989) Diaphragmatic hernia is observed mostly in adult dairy animals that are either in their late gestation or have recently calved (Smith, 2002). Diaphragmatic hernia may occur as a result of trauma, parturition, or progressive weakening of the diaphragm adjacent to a hardware perforation and reticuloperitonitis 
(Divers and Peek, 2008). The main cause of diaphragmatic herniain buffaloes has been reported to be foreign body syndrome while other conditions that increased intraabdominal pressure, for example, ruminaltympany, violent fall, advanced pregnancy, parturition process, chronic cough, and strainingdue to any reason could act as an exciting factor (Singh et al., 2006).

Treatment of diaphragmatic hernia requires surgery in two stages. The first stage involves a laparo-rumenotomy. During the second stage of surgery, the repair of the diaphraghmatic defect is done under general anaesthesia along with controlled ventilation (Singh et al., 2006). There is severe pain during the time of diaphragmatic herniorrhaphy. To achieve anaesthesia and relieve the pain different analgesic drugs are used which act on peripheral and central nervous system.

It is not easy to select a drug or a combination of drugs for general anaesthesia especially in ruminants. A variety of drugs are given to the patients that have different effects with overall aim of ensuring unconsciousness, amnesia, relaxation and analgesia.

General anaesthesia in bovines causes various complications like excessive salivation, regurgitation, tympany and cardiopulmonary depression. So a multiple drug approach (balanced anaesthesia and analgesia) is exploited to minimize and attenuate sensory, motor, sympathetic and parasympathetic reflex activities.

Glycopyrrolate is a preanaesthetic drug which stimulates cardiac reflex and blocks vagus reflex, thus prevents or inhibits cardiac inhibitory effect of Xylazine. Xylazine administration produces tachycardia (Khan et al., 2007a) in buffalo calves. Disadvantage of Glycopyrrolate to produce tachycardia and also associated to increase in oxygen demand which may result in arrhythmias or reduced cardiac contractility (Hall and Clarke, 1991). Glycopyrrolate-Acepromazine-XylazineThiopentone and Glycopyrrolate-AcepromazineXylazine-Ketamine combination offset the bardycardiac effects of Acepromazine and Xylazine and maintained heart rate and respiratory rate within normal limits throughout the period of observation in buffaloes undergoing diaphragmatic herniorrhaphy (Ninu, 2009). GlycopyrrolateXylazine-Pentazocine/ Butorphanol- Ketamine were considered safe during diaphragmatic herniorrhaphy (Satbir, 2011). Xylazine is typical $\alpha_{2}$-adrenoceptor agonist and exerts its effect accordingly. In cattle administration of Xylazine $(0.5 \mathrm{mg} / \mathrm{kg}$, IM) produced deep sedation with animal going into lateral recumbency (Hall and Clarke, 1969).Atropinebutorphanol-xylazine-ketamine-propofol was found safe anaesthetic combination in buffaloes undergoing diaphragmatic herniorraphy (Pushpender, 2012).

Ketamine is a dissociative anaesthetic that is used for induction/maintenance of anaesthesia in many species. It has the tendency to cause catalepsy and occasional seizers (Pageat, 1986). Propofol was found safe intravenous anaesthetic to induce general anaesthesia in buffaloes (Ratnesh, 2010).

Although a common concern for the welfare of the animals is shared, the prevention and alleviation of pain has not always been implemented effectively. Misconceptions about the nature and significance of pain, difficulties in recognizing its severity and uncertainly as to the most appropriate therapy have all hampered progress in this area, particularly in bovines.

Post-operative pain is commonly treated by NSAID / opioid (Dar et al., 2013). Nonsteroidal anti-inflammatory drugs (NSAIDs) are used extensively in veterinary 
practice for their analgesic, anti-inflammatory and antipyretic effects. NSAIDs have been reported to be extremely effective postoperative analgesics (Slingsby and Pearson, 2000; Mathews, 2001).

Meloxicam is an oxicam (enolic acid) derivative. Meloxicam has preferential COX-2 activity and is also a mild inhibitor of COX-1 in platelets and kidneys (Deneuche et al., 2004). It is indicated for the management of inflammation and pain arising from acute and chronic diseases (Doig et al., 2000; Lascelles et al., 2001). Flunixin-meglumine is a carboxylic acid NSAID and a potent inhibitor of cyclooxygenase (Lees et al., 1987; Semrad et al., 1985). Tolfenamic acid belongs to the fenamate group and is a potent inhibitor of cyclo-oxygenase enzyme. Meloxicam, Tolfenamic acid and Flunixin-meglumine have not been tried earlier as pre-emptive analgesia in combination with GlycopyrrolateXylazine-Ketamine anaesthesia in buffaloes undergoing diaphragmatic harniorrhaphy (D.H.). Therefore, the present study was undertaken to comparative Biochemical evaluation of three different treatement groups viz

Group 1 Glycopyrrolate - Xylazine Meloxicam - Ketamine in buffaloes undergoing diaphragmatic herniorrhaphy.

Group 2 Glycopyrrolate - Xylazine Tolfenamic acid - Ketamine in buffaloes undergoing diaphragmatic herniorrhaphy.

Group 3 Glycopyrrolate -Xylazine - Flunixinmeglumine - Ketamine in buffalo undergoing diaphragmatic herniorrhaphy.

\section{Materials and Methods}

The present investigation was conducted on eighteen clinical cases of buffaloes suffering from diaphramatic hernia presented to the
Teaching Veterinary Clinical Complex, LUVAS, Hisar from August 2013 to May 2014.

Diaphragmatic hernia was confirmed by radiography and rumenotomy. In positive cases, the ruminal contents were evacuated completely by laparo-rumenotomy and thereafter diaphragmatic hernia repair was done under general anaesthesia. Each animal was weighed before the diaphragmatic herniorraphy for calculating the proper dose of drugs used for general anaesthesia and kept off feed and water after laparo-rumenotomy and these animals were kept strictly on fluid therapy to avoid regurgitation during operation.

The animals were divided into three groups of six animals each. Pilot trials were done to standardize the dose rates and route of administration of different drugs.

Rectal temperature, heart rate (by auscultation) and respiration rate were recorded just before administration of the $\operatorname{drug}(\mathrm{s})$ along with the ambient temperature to form the base values. The blood samples were collected from jugular venipuncture before rumenotomy i.e., before administration of the drugs, before diaphragmatic herniorraphy, 15 minutes after administration of Meloxicam/ Tolfenamic acid/ Flunixin-meglumine, 5 minutes after administration of Ketamine, after complete recovery from the effects of the drugs and at 24 hour after recovery.

Various physiological parameters were recorded at before rumenotomy, before diaphragmatic herniorrhaphy, 15 minutes after Glycopyrrolate, 10 minutes after Xylazine, and 15 minutes after Meloxicam/Tolfenamic acid/Flunixin-meglumine administration at recovery and 24 hours after diaphragmatic herniorrhaphy. 
The blood samples were collected in EDTA test tubes, for harvesting plasma for biochemical parameters and and in one set of test tube containing sodium fluoride solution (3.8\%) for determining plasma glucose (1:10). After collection of blood samples, drugs were administered in accordance with the protocol.

For blood biochemical studies (urea nitrogen, creatinine, total plasma proteins, albumin), plasma was harvested from the EDTA blood by centrifugation at $3000 \mathrm{rpm}$ for 15 minutes and was stored at $-20 \mathrm{C}$ and utilized for analysis.

For plasma glucose estimation, blood collected in test tubes containing sodium fluoride $(3.8 \%)$ was centrifuged at $3000 \mathrm{rpm}$ for 15 minutes and the plasma was stored at $20^{\circ} \mathrm{C}$.

The plasma glucose, urea nitrogen, creatinine, total proteins and plasma albumin were estimated by an Erba XL-200 model fully Automated Random Access Clinical Chemistry Analyzer.

\section{Statistical analysis}

The statistical analysis of data was done by one-way-analysis of variance and Duncan's multiple range test (Duncan, 1955).

\section{Results and Discussion}

The study was conducted on eighteen clinical cases of diaphragmatic hernia presented in TVCC, Hisar and these were divided into three groups of six animals each.

All the parameters listed below were observed/recorded before the animals were operated for rumenotomy and were taken as base values. The results obtained were as follow (Table 1-3).

Group 1
The plasma glucose level showed progressive non- significant increase after 15 minutes of Meloxicam administration, significant increase at five minutes after Ketamine administration and at recovery was observed but after 24 hours glucose value returned near base values. The increase was within the physiological range having no clinical importance. During the period of anaesthesia there is decrease in basal metabolic rate of the animal and muscular activity is negligible, so utilization of glucose by muscles is also decreased probably causing slight increase in glucose concentration. However, since hyperglycaemia produced was transient in nature, a clinical significance could not be attached. Significant incresase in plasma glucose level also occurred during anaesthesia due to continous administration of $5 \%$ dextrose saline solution till the animal recovered. Stimuli such as pain, trauma, hypovolumia and anxiety can stimulate sympathetic nervous system which triggers release of catecholamines from adrenal medulla (Bright and Lantz, 1985). Excessive release of catecholamines inhibits pancreatic production of insulin and its peripheral activity and thereby may cause hyperglycaemia (Moore, 1972). Excessive sympathetic stimulation after surgical trauma can also increase the rate of metabolic activities like glycogenolysis in the liver and muscles leading to release of glucose into blood. During anaeasthesia and surgery hyperglycemia occur due to gluconeogenesis by release of glucagon hormone (Thurmon et al., 1996). Xylazine may directly stimulate hepatic glucose production via alpha adrenoceptors in liver (Tranquilli et al., 1984). The stress of digestive disorders might have resulted in hyperglycemia due to glcogenolytic effect of released corticosteroids from adrenal gland (Sujataand Uppal, 2006). Ninu, 2009 observed non-significant increase in plasma glucose level after Glycopyrrolate- 
Acepromazine-Xylazine-Ketamine combination in buffaloes till complete recovery from effects. Non-significant variations were observed in all other blood biochemical parameters during the anaesthetic protocol. Total plasma protein and plasma albumin values fluctuated non-significantly within normal range indicating NSAIDs administered pre-operatively were effective in preventing increase in adrenal activity, protein catabolism and suppressing the inflammatory cascade at site of surgery.

Antipyretic properties of NSAIDs resulted in reduced protein degradation and decreased cortisol and catecholamine response (Asoh $e t$ al., 1987). No significant changes in total plasma protein values following surgery in dogs have been reported by (Mills et al., 1992). The mean total plasma protein, albumin and globulin in animals suffering from diaphragmatic herniorrhaphy did not differ significantly from the control group (Sujataand Uppal, 2006). However Peshin et al., (1988) reported hypoproteinemia and hypoalbuminemia in cases of diaphragmatic herniorrhaphy. Toor, 2003 reported increased total plasma protein in ruminoreticular, omasal and abomassal disorders in bovines.

The plasma creatinine and BUN values fluctuated non-significantly within normal range. When administered pre-operatively single dose of Meloxicam did not cause clinically important alterations of renal function in many canine and feline studies (Mathews et al., 2001; Deneuche et al., 2004; Laredo et al., 2004). Toxic side effects of NSAIDs are well known in small animals and equines. Hypotension and increased sympathetic tone which are common side effects of surgery and anaesthesia, cause renal blood flow a prostaglandin dependent event. Subsequent inhibition of prostaglandin production by NSAIDs can adversely effect GFR and renal haemodynamics (Crandell et al., 2004). Drugs that preferentially inhibit COX-2 would presumably have a lower risk of renal injury (Papich, 2000). However increased plasma creatinine and BUN in cases of diaphragmatic hernia have been reported (Rathore and Sethuraman, 1979; Peshin et al., 1988; Sujataand Uppal, 2006). Increased plasma creatinine and BUN could be related to anorexia, starvation, decreased ruminoreticular activity and dehydration as catabolism is accelerated under such conditions (Toor, 2003).

\section{Group 2}

The plasma glucose level significantly and progressively increased to $199.40 \pm 24.43$ $\mathrm{mg} / \mathrm{dl} 5$ minutes after Ketamine administration and $245.30 \pm 19.76 \mathrm{mg} / \mathrm{dl}$ at the time of recovery in comparison to the base value $134.13 \pm 13.40 \mathrm{mg} / \mathrm{dl}$ but after 24 hours the plasma glucose value declined to $103.83 \pm 14.13 \mathrm{mg} / \mathrm{dl}$.

During the period of anaesthesia there is decrease in basal metabolic rate of the animal and muscular activity is negligible, so utilization of glucose by muscles is also decreased probably causing slight increase in glucose concentration. However, since hyperglycaemia produced was transient in nature, a clinical significance could not be attached. Significant increase in plasma glucose level also occurred during anaesthesia due to continuous administration of 5\% dextrose saline solution till the animal recovered. Stimuli such as pain, trauma, hypovolumia and anxiety can stimulate sympathetic nervous system which triggers release of catecholamines from adrenal medulla (Bright and Lantz, 1985). Excessive release of catecholamines inhibits pancreatic production of insulin and its peripheral activity and thereby may cause hyperglycaemia (Moore, 1972). 
Following drugs were used in different combinations for repair of diaphragmatic hernia

\begin{tabular}{|c|c|c|}
\hline Drugs & $\begin{array}{l}\text { Dose rate } \\
(\mathrm{mg} / \mathrm{kg})\end{array}$ & $\begin{array}{l}\text { Time and route of administration } \\
\text { of different drugs }\end{array}$ \\
\hline Glycopyrrolate & 0.01 & Glycopyrrolate(I/M) \\
\hline Xylazine & 0.04 & 20 minutes \\
\hline Meloxicam & 0.5 & \\
\hline Tolfenamic acid & 4 & Xylazine(I/M) \\
\hline Flunixin-meglumine & 2.2 & \\
\hline Ketamine+ Xylazine & $1+0.04$ & $\begin{array}{l}\text { Meloxicam }(\mathrm{I} / \mathrm{M}) / \text { Tolfenamic acid }(\mathrm{I} / \mathrm{M}) / \\
\text { Flunixin-meglumine }(\mathrm{I} / \mathrm{V}) \\
\text { Ketamine + Xylazine }(\mathrm{I} / \mathrm{V})\end{array}$ \\
\hline
\end{tabular}

Analgesic repeated after 12 and 24 hours after recovery.

${ }^{1}$ Pyrolate $^{\mathrm{R}}$ - Glycopyrrolate injection U.S.P. $(0.2 \mathrm{mg} / \mathrm{ml})$, Neon Laboratories Limited, 28, Mahal Ind. Estate, M. Caves Road, Andheri [East], Mumbai - 400093, INDIA.

${ }^{1}$ Xylazine - Xylazine injection $(23.32 \mathrm{mg} / \mathrm{ml})$, Indian Immunologicals Ltd., Gollapadu, Guntur Dist- 522408 A.P.

${ }^{1}$ Aneket - Ketamine Hydrochloride Injection I.P. 50mg/ml, Neon Laboratories Limited, 28, Mahal Ind. Estate, M. Caves Road, Andheri [East], Mumbai - 400093, INDIA.

${ }^{1}$ Flunimeg ${ }^{\text {TM }}$-Flunixin-meglumine Injection I.P. $50 \mathrm{mg} / \mathrm{ml}$, Zydus AHL, Astron Tech Park, satellite cross roads Ahmedabad-380015, INDIA..

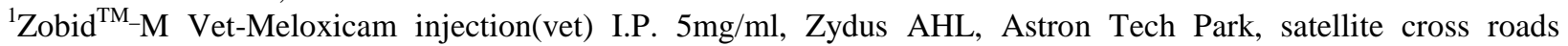
Ahmedabad-380015, INDIA..

${ }^{1}$ Maxxtol $^{\mathrm{TM}}$-Tolfenamic injection I.P. 40mg/ml, Intas Pharmaceuticals Ltd. Matoda-382210 Ahmedabad, INDIA.

Table.1 Effects of Glycopyrrolate-Xylazine-Meloxicam-Ketamine combination on biochemical parameters. Table showing arithmetic mean values obtained before and at various intervals after its administration in six buffaloes. Mean values presented with respective standard errors $( \pm)$

\begin{tabular}{|l|c|c|c|c|c|c|}
\hline Parameters & \multicolumn{1}{|c|}{ T1 } & T2 & T3 & T4 & T5 & T6 \\
\hline $\begin{array}{l}\text { Plasma glucose } \\
\text { (mg/dl) }\end{array}$ & $111.05 \pm 24.81^{\mathrm{a}}$ & $84.68 \pm 9.85^{\mathrm{a}}$ & $111.55 \pm 15.48^{\mathrm{a}}$ & $169.28 \pm 28.07^{\mathrm{ab}}$ & $231.50 \pm 49.50^{\mathrm{b}}$ & $84.66 \pm 10.33^{\mathrm{a}}$ \\
\hline BUN (mg/dl) & $27.57 \pm 4.70^{\mathrm{a}}$ & $32.43 \pm 5.22^{\mathrm{a}}$ & $31.10 \pm 5.67^{\mathrm{a}}$ & $23.90 \pm 4.38^{\mathrm{a}}$ & $32.05 \pm 4.80^{\mathrm{a}}$ & $31.25 \pm 4.85^{\mathrm{a}}$ \\
\hline Creatnine(mg/dl) & $2.06 \pm 0.36^{\mathrm{a}}$ & $2.21 \pm 0.34^{\mathrm{a}}$ & $2.19 \pm 0.38^{\mathrm{a}}$ & $1.74 \pm 0.42^{\mathrm{a}}$ & $1.76 \pm 0.44^{\mathrm{a}}$ & $2.22 \pm 0.28^{\mathrm{a}}$ \\
\hline Albumin (g/dl) & $2.56 \pm 0.23^{\mathrm{a}}$ & $2.82 \pm 0.23^{\mathrm{a}}$ & $1.97 \pm 0.44^{\mathrm{a}}$ & $2.67 \pm 0.63^{\mathrm{a}}$ & $2.58 \pm 0.21^{\mathrm{a}}$ & $2.29 \pm 0.23^{\mathrm{a}}$ \\
\hline $\begin{array}{l}\text { Total protein } \\
\text { (g/dl) }\end{array}$ & $6.47 \pm 0.67^{\mathrm{a}}$ & $6.93 \pm 0.82^{\mathrm{a}}$ & $4.71 \pm 1.15^{\mathrm{a}}$ & $6.12 \pm 1.26^{\mathrm{a}}$ & $6.58 \pm 0.74^{\mathrm{a}}$ & $5.92 \pm 0.50^{\mathrm{a}}$ \\
\hline
\end{tabular}

Means with different superscripts vary significantly $(P<0.05)$

T1: Before Rumenotomy, T2: Before Diaphragmatic herniorrhaphy, T3: 15 minutes after Meloxicam, T4: 5 minutes after Ketamine, T5: At recovery, T6: 24 hours after Diaphragmatic herniorrhaphy. 
Table.2 Effects of Glycopyrrolate-Xylazine-Tolfenamic acid-Ketamine combination on biochemical parameters. Table showing arithmetic mean values obtained before and at various intervals after its administration in six buffaloes. Mean values presented with respective standard errors $( \pm)$

\begin{tabular}{|l|c|c|c|c|c|c|}
\hline Parameters & T1 & T2 & T3 & T4 & T5 & T6 \\
\hline $\begin{array}{l}\text { Plasma } \\
\text { glucose } \\
(\mathbf{m g} / \mathbf{d l})\end{array}$ & $134.13 \pm 13.40^{\mathrm{a}}$ & $111.98 \pm 14.73^{\mathrm{a}}$ & $111.08 \pm 15.76^{\mathrm{a}}$ & $199.40 \pm 24.43^{\mathrm{b}}$ & $245.30 \pm 19.76^{\mathrm{b}}$ & $103.83 \pm 14.13^{\mathrm{a}}$ \\
\hline $\begin{array}{l}\text { BUN } \\
(\mathbf{m g} / \mathbf{d l})\end{array}$ & $35.56 \pm 4.80^{\mathrm{a}}$ & $38.21 \pm 4.0^{\mathrm{a}}$ & $38.44 \pm 4.0^{\mathrm{a}}$ & $35.55 \pm 4.74^{\mathrm{a}}$ & $38.39 \pm 3.93^{\mathrm{a}}$ & $38.01 \pm 4.04^{\mathrm{a}}$ \\
\hline $\begin{array}{l}\text { Creatinine } \\
(\mathbf{m g} / \mathbf{d l})\end{array}$ & $1.90 \pm 0.27^{\mathrm{a}}$ & $1.99 \pm 0.26^{\mathrm{a}}$ & $2.00 \pm 0.24^{\mathrm{a}}$ & $2.09 \pm 0.23^{\mathrm{a}}$ & $2.02 \pm 0.29^{\mathrm{a}}$ & $2.05 \pm 0.27^{\mathrm{a}}$ \\
\hline $\begin{array}{l}\text { Albumin } \\
\text { g/dl) }\end{array}$ & $3.01 \pm 0.22^{\mathrm{a}}$ & $2.99 \pm 0.23^{\mathrm{a}}$ & $2.82 \pm 0.15^{\mathrm{a}}$ & $2.78 \pm 0.18^{\mathrm{a}}$ & $2.74 \pm 0.21^{\mathrm{a}}$ & $2.57 \pm 0.23^{\mathrm{a}}$ \\
\hline $\begin{array}{l}\text { Total } \\
\text { protein } \\
\text { g/dl) }\end{array}$ & $6.74 \pm 0.56^{\mathrm{a}}$ & $6.62 \pm 0.58^{\mathrm{a}}$ & $6.53 \pm 0.66^{\mathrm{a}}$ & $6.53 \pm 0.57^{\mathrm{a}}$ & $6.18 \pm 0.44^{\mathrm{a}}$ & $5.50 \pm 0.53^{\mathrm{a}}$ \\
\hline
\end{tabular}

Means with different superscripts vary significantly $(P<0.05)$

T1: Before Rumenotomy, T2: Before Diaphragmatic herniorrhaphy, T3: 15 minutes after Tolfenamic acid, T4: 5 minutes after Ketamine, T5: At recovery, T6: 24 hours after Diaphragmatic herniorrhaphy.

Table.3 Effects of Glycopyrrolate-Xylazine-Flunixin-meglumine-Ketamine combination on biochemical parameters. Table showing arithmetic mean values obtained before and at various intervals after its administration in six buffaloes. Mean values presented with respective standard errors $( \pm)$

\begin{tabular}{|l|c|c|c|c|c|c|}
\hline Parameters & T1 & T2 & T3 & T4 & T5 & T6 \\
\hline $\begin{array}{l}\text { Plasma } \\
\text { glucose } \\
(\mathbf{m g} / \mathbf{d l})\end{array}$ & $84.00 \pm 2.19^{\mathrm{a}}$ & $93.40 \pm 10.78^{\mathrm{a}}$ & $102.75 \pm 12.01^{\mathrm{a}}$ & $168.23 \pm 16.31^{\mathrm{a}}$ & $313.05 \pm 64.38^{\mathrm{b}}$ & $98.43 \pm 12.41^{\mathrm{a}}$ \\
\hline $\begin{array}{l}\text { BUN } \\
(\mathbf{m g} / \mathbf{d l})\end{array}$ & $40.01 \pm 5.33^{\mathrm{a}}$ & $41.44 \pm 5.95^{\mathrm{a}}$ & $39.14 \pm 5.54^{\mathrm{a}}$ & $30.50 \pm 6.42^{\mathrm{a}}$ & $38.22 \pm 4.75^{\mathrm{a}}$ & $43.16 \pm 3.71^{\mathrm{a}}$ \\
\hline $\begin{array}{l}\text { Creatinine } \\
(\mathbf{m g} / \mathbf{d l})\end{array}$ & $2.82 \pm 0.58^{\mathrm{a}}$ & $2.80 \pm 0.56^{\mathrm{a}}$ & $2.60 \pm 0.59^{\mathrm{a}}$ & $2.72 \pm 0.52^{\mathrm{a}}$ & $2.73 \pm 0.49^{\mathrm{a}}$ & $2.77 \pm 0.53^{\mathrm{a}}$ \\
\hline $\begin{array}{l}\text { Albumin } \\
\text { (g/dl) }\end{array}$ & $3.52 \pm 0.11^{\mathrm{a}}$ & $3.47 \pm 0.07^{\mathrm{a}}$ & $3.50 \pm 0.15^{\mathrm{a}}$ & $3.48 \pm 0.14^{\mathrm{a}}$ & $3.49 \pm 0.16^{\mathrm{a}}$ & $3.40 \pm 0.10^{\mathrm{a}}$ \\
\hline $\begin{array}{l}\text { Total } \\
\text { protein } \\
\text { (g/dl) }\end{array}$ & $6.27 \pm 0.85^{\mathrm{a}}$ & $6.24 \pm 0.82^{\mathrm{a}}$ & $5.23 \pm 0.85^{\mathrm{a}}$ & $5.30 \pm 0.84^{\mathrm{a}}$ & $4.85 \pm 0.56^{\mathrm{a}}$ & $5.55 \pm 0.78^{\mathrm{a}}$ \\
\hline
\end{tabular}

Means with different superscripts vary significantly $(P<0.05)$

T1: Before Rumenotomy, T2: Before Diaphragmatic herniorrhaphy, T3: 15 minutes after Flunixin-meglumine, T4: 5 minutes after Ketamine, T5: At recovery, T6: 24 hours after Diaphragmatic herniorrhaphy. 
Excessive sympathetic stimulation after surgical trauma can also increase the rate of metabolic activities like glycogenolysis in the liver and muscles leading to release of glucose into blood. During anaesthesia and surgery hyperglycemia occur due to gluconeogenesis by release of glucagon hormone (Thurmon et al., 1996). Xylazine may directly stimulate hepatic glucose production via alpha adrenoceptors in liver (Tranquilli et al., 1984). The stress of digestive disorders might have resulted in hyperglycemia due to glycogenolytic effect of released corticosteroids from adrenal gland (Sujata and Uppal, 2006). Ninu, 2009 observed non-significant increase in plasma glucose level after GlycopyrrolateAcepromazine-Xylazine-Ketamine combination in buffaloes till complete recovery from effects. Non-significant variations were observed in all other blood biochemical parameters during the anaesthetic protocol. Tolfenamic acid did not cause any adverse effects on renal function, haematological and serum biochemical variables in healthy cats (Khwanjai et al., 2012). The mean values of serum glucose, aspartate aminotransferase (AST), alanineamino transferase (ALT), alkaline phosphatase (ALP), total bilirubin (TB), total protein (TP), albumin, globulin, creatinine, urea and uric acid of male and female rats of treatment group given Tolfenamic acid at 24 hours intervals for 14 days did not differ significantly from those of control animals (Patel et al., 2011). However, the level of BUN was found higher than normal range $20-30 \mathrm{mg} / \mathrm{dl}$. Increased plasma creatinine and BUN in cases of diaphragmatic hernia have been reported (Rathore and Sethuraman, 1979; Peshin et al., 1988; Sujata and Uppal, 2006). Increased plasma creatinine and BUN could be related to anorexia, starvation, decreased ruminoreticular activity and dehydration as catabolism is accelerated under such conditions (Toor, 2003).

\section{Group 3}

The plasma glucose level showed nonsignificant increase from base value $84.00 \pm 2.19 \mathrm{mg} / \mathrm{dl}$ to $93.40 \pm 10.78 \mathrm{mg} / \mathrm{dl}$ before diaphragmatic herniorrhaphy and then non-significantly increased to $102.75 \pm 12.01$ $\mathrm{mg} / \mathrm{dl} 15$ minutes after Flunixin-meglumine administration. The value non-significantly and progressively increased to $168.23 \pm 16.31$ $\mathrm{mg} / \mathrm{dl} 5$ minutes after Ketamine administration and then significantly increased to $313.05 \pm 64.38 \mathrm{mg} / \mathrm{dl}$ at the time of recovery in comparison to the base value $84.00 \pm 2.19 \mathrm{mg} / \mathrm{dl}$ but after 24 hours the plasma glucose value declined to $98.43 \pm 12.41$ $\mathrm{mg} / \mathrm{dl}$. During the period of anaesthesia there is decrease in basal metabolic rate of the animal and muscular activity is negligible, so utilization of glucose by muscles is also decreased probably causing slight increase in glucose concentration. However, since hyperglycaemia produced was transient in nature, a clinical significance could not be attached. Significant increases in plasma glucose level also occurred during anaesthesia due to continuous administration of $5 \%$ dextrose saline solution till the animal recovered. Stimuli such as pain, trauma, hypovolumia and anxiety can stimulate sympathetic nervous system which triggers release of catecholamines from adrenal medulla (Bright and Lantz, 1985). Excessive release of catecholamines inhibits pancreatic production of insulin and its peripheral activity and thereby may cause hyperglycaemia (Moore, 1972). Excessive sympathetic stimulation after surgical trauma can also increase the rate of metabolic activities like glycogenolysis in the liver and muscles leading to release of glucose into blood. During anaeasthesia and surgery hyperglycemia occur due to gluconeogenesis by release of glucagon hormone (Thurmon et al., 1996). Xylazine may directly stimulate hepatic glucose production via alpha 
adrenoceptors in liver (Tranquilli et al., 1984). The stress of digestive disorders might have resulted in hyperglycemia due to glcogenolytic effect of released corticosteroids from adrenal gland (Sujata and Uppal, 2006). The values of all other biochemical parameters fluctuated nonsignificantly at different intervals. However the level of BUN was found to higher than normal range $20-30 \mathrm{mg} / \mathrm{dl}$. Increased plasma creatinine and BUN in cases of diaphragmatic hernia have been reported (Rathore and Sethuraman, 1979; Peshin et al., 1988; Sujata and Uppal, 2006). Increased plasma creatinine and BUN could be related to anorexia, starvation, decreased ruminoreticular activity and dehydration as catabolism is accelerated under such conditions (Toor, 2003).

The present study concludes that amid of plasma glucose levels rest of the biochemical parameters does not vary significantly. Only in group 2 plasma albumin and total protein values shown on significant progressive decrease in their respective base values at different time intervals of treatment regime.

A non-significant decrease was observed in plasma glucose levels in group 1 and 2 while in group 3 it showed non-significant increase.

\section{References}

Asoh, T., Shirosaka, C., Uchida, I., and Tsudi, H. 1987. Effects of indomethacin on endocrine responses and nitrogen loss after surgery. Ann.Surg. 206: 770-776.

Bright, R. M. and Lantz, G. L. 1985. Metabolism of surgical patients. Textbook of small animal surgery Vol. 1, Slatter, D.H. (Ed.), W.B. Saunders Company, Philadelphia, pp 82-90.

Carrick, B., Mark, G., Papich; Dorothy, M., Middleton; Jonathan, M., Naylor; and Hugh, G. G. 1989. Clinical and Pathological Effects of Flunixin- meglumine Administration to Neonatal Foals. Can J Vet Res; 53: 195-201.

Crandell, D. E., Mathews, K. A. and Dyson, D. H. 2004. Effect of meloxicam and carprofen on renal function when administered to healthy dogs prior to anesthesia and painful stimulation. Am. J. Vet. Res. 65: 1384-1390.

Dar, S. H., Bhadwal, M. S. and Zama, M. M. S. 2013. Post-operative analgesia in dogs by Tramadol and Nimesulide. Indian Vet. J., 90(2): 32-34.

Deneuche, A. J., Dufayet, C., Goby L., Fayolle, P. and Desbois, C. 2004. Analgesic comparison of meloxicam and ketoprofen for orthopedic surgery in dogs. Vet. Surg. 33: 650-660.

Divers, T.J. and Smith, B.P. 1979. Diaphragmatic hernia in a cow,"Journal of the American Veterinary Medical Association, vol.175, no. 10, pp. 10991100.

Doig, P. A., Purbrick, K. A., Hare J. E. and Mckeown, D. B. 2000. Clinical efficacy and tolerance of meloxicam in dogs with chronic osteoarthritis. Can. Vet. J. 41: 296-300.

Hall, L. W. and Clarke, K. W. 1969. "Xylazine"- a new sedative for horses and cattle. Vet. Rec. 85: 512-517.

Hall, L. W. and Clarke, K. W. 1991. Principles of sedation, analgesia and premedication. In: Veterinary Anaesthesia. $9^{\text {th }}$ edn. Baillire Tindal, London. pp. 75-112.

Khan, I., Kumar, A; Singh, J; Peshin, P.K. and Singh, S. 2007 a. Evaluation of glycopyrrotate as an anticholinergic in buffalo calves (Bubalus bubalis). Italian J. Anim. Sci. 6(2): 1007-1010.

Khwanjai, V., Chuthatep, S., Durongphongtorn, S. and YibchokAnun, S. 2012. Evaluating the effects of 14-day oral vedaprofen and tolfenamic acid treatment on renal function, hematological and biochemical profiles 
in healthy cats. Vet.Pharmacol.Ther. 35(1):8-13.

Kumar, A. and Thurmon, J. C. 1979. Cardiopulmonary, hemocytologic and biochemical effects of xylazine in goats. Lab. Anim. Sci.29: 486-491.

Laredo, F. G., Belda, E., Murciano, J., Escobar, M. and Navarro, A., 2004. Comparison of the analgesic effects of meloxicam and carprofen administered preoperatively to dogs. Vet.Rec. 155: 667-671.

Lascelles, B. D. X., Henderson, A. J. and Hackett, I. J. 2001. Evaluation of the clinical efficacy of meloxicam in cats with painful locomotor disorders. $J$. Small Anim. pract. 42: 587-593.

Lees, P., Ewins, C.P., Taylor, J.B.O. and Sedgwick, A.D. 1987. Serum thromboxane in the horse and its inhibition by aspirin, phenylbutazone and flunixin. Br. Vet. J., 143: 462-476.

Mathews, K. A. 2001 Perioperative use of non-steroidal anti-inflamatory analgesics. Proceedings World Small Animal Vet. Assoc. Congress. (WSAVA-2001).

Mills, D. L., Hauptman, J. G. and Richter, M. 1992. Preoperative and postoperative hemostatic profiles of dogs undergoing ovariohysterectomy. Cornell Vet. 82: 465-470.

Moore, F. D. 1972. Homeostasis, bodily changes in trauma and surgery. Sabiston, D. C. J. (Ed.) $10^{\text {th }}$ Edn. W. B. Saunders, Philadelphia, p: 26.

Ninu, A. R. 2009. Evaluation of anaesthetic protocols in diaphragmatic herniorrhaphy in buffaloes (Bubalusbubalis). MVSc. Thesis. CCS Haryana Agricultural University. Hisar.

Pageat, P. 1986. Clinical study of recurrent hallucination after ketamine anaesthesia in dogs and cats: 39 cases. PratiqueMedicale and Chirugicale de l' Animal de Compagnie. 21: 185-190.
Papich, M. G. 2000. Pharmacological considerations for opiate analgesics and non-steroidal anti-inflammatory drugs. Vet Clin North Am Small AnimPract. 30: 757-770.

Patel, S. D., Sadariya, K. A., Gothi, A. K., Patel, U. D., Jain, M.R., Bhavsar.S. K. and Thaker, A. M. 2011. Safety of tolfenamic acid following repeated intramuscular administration in wistar rats. Pharma Sci. Monitor Int. J. Pharm. Sci., 2: 79-85.

Peshin, P. K., Krishnamurthy, D. and Mehta, I. J. 1988. Haematological and biochemical changes in bovine diaphgramatic hernia. Indian J. Anim. Sci., 58: 764-766.

Pushpender 2012 Evaluation of XylazineKetamine-Propofol anaesthesia in buffaloes undergoing diaphragmatic herniorrhaphy. $\quad M V S c \quad$ Thesis LalaLajpatRai University of Veterinary and Animal Sciences

Rathor, S. S. and Sethuraman, V. 1979. Clinical, haematological and biochemical studies in secondary indigestion in bovines due to traumatic reticulitis and diaphragmatic hernia. Indian J. Anim. Sci. 49: 703-06.

Ratnesh, 2010. Evaluation of Propofol as intavenous anaesthetic to induce general anaaesthesia in buffalo calves. MVSc Thesis, CCS Haryana Agricultural University, Hisar.

Sahu, A., Chawla, S.K., Krishnamurthy, D. 2003. Diaphragmatic herniorrhaphy in buffaloes: clinical evaluation of 72cases," Indian Journal of Veterinary Surgery, vol. 24, pp. 33-34.

Saini, N.S., Kumar, A., Mahajan, S.K. and. Sood, A.C. 2007. The useof ultrasonography, radiography, and surgery in the successful recovery from diaphragmatic hernia in a cow," Canadian Veterinary Journal, vol. 48, no. 7, pp. 757-759, 
Satbir 2011. Comparative evaluation of Pentozocine lactate, Butorphanol tartrate and Dipyrone in buffaloes undergoing diaphragmatic herniorrhaphy. MVSc Thesis LalaLajpatRai University of Veterinary and Animal Sciences.

Semrad, S. D., Hardee, G. E., Hardee, M. M. 1985. Flunixin-meglumine given in small doses: pharmacokinetics and prostaglandin inhibition in healthy horses. Am. J. Vet. Res., 46: 2474-2479.

Singh, S., Kumar, A., Singh, J., Singh, S. and Peshin, P. K. 2006. Haemodynamic effects of atropine-diazepamthiopentone anaesthesia in buffalo calves. Indian J. Vet. Res. 15(1): 22-30.

Slingsby, L. S. and Waterman-Pearson, A. E. 2000. Postoperative analgesia in the cat after ovariohysterectomy by use of carprofen, ketoprofen, meloxicam or tolfenamic acid. J Small Anim Pract.41: 447-450.

Smith, B.P. 2002"Diaphragmatic hernia," in Large Animal InternalMedicine, p. 729, Mosby, St. Louis, Mo, USA.
Sobti, V.K., Sharma, S.N., Singh, K. and Rathor, S.S. 1989. Diaphragmatic hernia in buffalo bulls," Indian Veterinary Journal, vol. 66, p. 866,

Sujata, T. and Uppal, S. K. 2006. Studies on haemato-biochemical profile of diaphgramatic hernia in buffaloes. Indian J. Vet. Pathol. 30(1): 64-65

Thurmon, J. C., Tranquilli, W. J. and Benson, G. J. 1996 Consideration for general anaesthesia and perioperative pain and distress. In. Lumb and Jones veterinary anaesthesia, $3^{\text {rd }}$ Edn., Baltimore M.D., Williams and Wilkins. Pp: 22, 40-60, 215-223.

Toor, A. S. 2003. Clinical studies on the surgically treated ruminoreticular, omassal and abomassal disorders in bovines. M.V.Sc Thesis, Punjab Agricultural University, Ludhiana.

Tranquilli, W. J., Thurmon, J. C., Neff-Davis, C. A. and Davis, L. E. 1984. Hyperglycemia and hypoinsulinemia during xylazine-ketamine anaesthesia in thorough bred horses. Am. J. Vet. Res. 45(1): 11-14.

\section{How to cite this article:}

Lokesh, Praveen Kumar, Anup Yadav, Umed Singh Mehra, Rishi Tayal, Rajendra Yadav and Pankaj Kumar. 2018. Biochemical Studies in Buffaloes Treated with Various NSAIDS Protocols Affected with Diaphragmatic Hernia. Int.J.Curr.Microbiol.App.Sci. 7(11): 29963006. doi: https://doi.org/10.20546/ijcmas.2018.711.344 